\title{
Chapter 14 \\ Impoverishment and Social \\ Fragmentation in Housing Estates \\ of the Paris Region, France
}

\author{
Christine Lelévrier and Talia Melic
}

\begin{abstract}
This chapter provides a historical overview of the construction and renewal programmes of large housing estates in Paris and its surrounding suburbs. We examine neighbourhood level data on two large housing estates to provide insight into the processes of poverty and ethnic concentration within these sites. We also examine the impact of urban renewal programmes on demographic and physical change. We argue that while the urban form of the large housing estate is gradually disappearing from the housing landscape, poverty and ethnic concentration have not disappeared, and micro-fragmentation between different social levels has become more pronounced. By including individual residential trajectories and mobilities in our analysis - and going beyond the traditional gentrification/ displacement nexus - we demonstrate that current renewal policies are at risk of creating new peripheries of exclusion and segregation at a regional level. At the same time, examination of the two case studies allows for a more nuanced perspective, which suggests that housing estates continue to play an important role in providing affordable housing and residential opportunities for local residents.
\end{abstract}

Keywords Fragmentation - Housing estates - Paris, France · Poverty Social mixing

\subsection{Introduction}

In France, the term 'grands ensembles' is widely used to describe large-scale social housing estates, built after World War II in order to house both workers and those who had been displaced from the old, derelict slums of the country's city centres (Droste et al. 2014; van Kempen et al. 2005). Between 1953 and 1973, the number

\author{
C. Lelévrier $(\bowtie) \cdot T$. Melic \\ University of Paris-Est, Lab’Urba, UPEC, Marne-la-Vallée, France \\ e-mail: lelevrier@u-pec.fr \\ T. Melic \\ e-mail: talia.melic@gmail.com \\ (C) The Author(s) 2018 \\ D. B. Hess et al. (eds.), Housing Estates in Europe, The Urban Book Series,


of social housing units in France increased from less than 500,000 to more than 3 million (Tomas et al. 2003; Le Goullon 2010). 43\% of the estates built during this period were situated within the Île-de-France region-one of the 18 regions of France and including the city of Paris - predominantly beyond the periphery of the city, in its suburbs. This chapter analyses the evolution of these housing estates within the Île-de-France region.

Although the grands ensembles were initially welcomed as a major step forward in housing quality and living standards, by the 1970s the planning principles underpinning the grands ensembles were beginning to be seriously questioned. In the mid-1970s, the first efforts were undertaken to renovate estate buildings. By the 1980s, housing estates were widely perceived as places that concentrated poverty and social problems, and many had become synonymous with the notion of a 'deprived neighbourhood'.

Since 2003, major demolition and tenure diversification programmes have sought to deconcentrate poverty within housing estates. These efforts have taken on greater significance in the wake of France's riots of November 2005, which brought into focus the extent to which the spatial concentration of poverty, and the structural dimensions of ethnic discrimination are real problems with profound social consequences (Dikec 2017).

Despite 15 years since their initial implementation, current policy approaches to urban renewal and social mixing remain strongly debated amongst academics and officials - as to what extent they represent viable and efficient responses to poverty concentration in public housing estates (Blanc 2010; Bolt et al. 2010; Levy-Vroelant 2007; Goulard and Puponni 2010). Given these divergent opinions, we seek to provide greater insight into the demographic and physical changes taking place within housing estates targeted by urban renewal programmes. We have chosen to focus on two housing estates located in the suburbs of Paris, in the Île-de-France region, in consideration of the following questions: What insights do historical and contextual factors provide into the process of poverty concentration within these housing estates? Have urban renewal programmes managed to reduce the concentration of social and ethnic groups within each estate? How have the changes in demographics and in the built environment, resulting from these programmes, transformed the urban landscape? How should such changes be theorised, and are the concepts 'gentrification' and 'displacement' sufficiently nuanced to capture the complexity of change taking place within these estates? What contextual factors might account for differences in residential trajectories across the two sites?

As these estates are grounded in their specific historical and regional contexts, in the first part of this chapter, we provide an overview and analysis of the concentration and degradation processes within large housing estates in France, including how perceptions and policies have evolved over time.

In the second part of the chapter, we examine neighbourhood level data from two housing estates in different suburbs of Paris, in order to provide a nuanced picture of their respective trajectories and the approaches pursued by each municipality to improve the built environment and social life. The first site, the 
'4000' housing estate, comprises 4000 units and is located in the suburban municipality of La Courneuve, in the northeast of Paris. The '4000' estate alone represents $26.6 \%$ of La Courneuve's total housing stock. The second site

is located in the suburban municipality of Orly, in the south of Paris, and comprises 5400 units. The estate represents $58.6 \%$ of Orly's total housing stock.

In the final part of the chapter, we draw on these cases to critically analyse the impact of urban transformation on social outcomes, highlighting common trends and diverging trajectories of change, ranging from impoverishment to micro-fragmentation.

In pursuing these questions, we come up against three major data limitations. First, in relation to housing, no official data on 'housing estates' is collected in France. Historians agree upon a general set of criteria for the grands ensembles, but it remains a rather loose definition. Though their boundaries have shifted as a result of various policy changes, our analysis will be based around the concept of 'priority neighbourhoods', as defined by France's City Policy—a social and urban policy that has specifically targeted housing estates since the 1980s.

Second, in relation to individuals, comprehensive data on income levels in France has only been available since 2002, making it difficult to accurately establish trends in poverty levels over time. Furthermore, very little of this data is disaggregated to a neighbourhood level. Therefore, as indicators of poverty levels, we draw on unemployment and social welfare allocation figures. Third, there is a lack of official data regarding ethnicity: in accordance with France's 'colour-blind' approach, ethnic origin is not recorded in its census nor in other major surveys (Alba and Silberman 2002). The census does collect comparable data on 'nationality', a legal category that distinguishes 'foreigners' from 'French citizens', and in some cases data on 'immigrants', defined as being born a foreigner in a foreign country. In light of this limitation, we draw on various data sources to examine ethnic segregation in housing estates.

\subsection{Producing and Improving Housing Estates: State-Led Policy in a Regional Context}

The evolution of housing estates in the Paris region is closely tied to France's national urban policy framework. A timeline, consisting of five main periods, can be constructed as follows for France's housing estate development in the post-World War Two era:

1953: The beginning of large-scale housing estate production, seen as a symbol of progress and modernity, and supported through financing tools from the State and private companies.

1958: Advances in land regulation, planning and funding tools to produce large housing estates through the creation of Priority Zones to be Urbanised; the 
beginning of the first major urban renewal programme targeting private tenure housing in city centres.

1973: The number of housing estates built reaches its peak. In the same year, the construction of estates larger than 500 units is formally halted, following the release of the 'Guichard circular'.

1977: Housing policies are significantly reformed, a home ownership programme is introduced which leads to the large-scale departure of middle-class housing estate residents.

1983-2003: A period of successive urban and social policies target housing estates, now seen as sites of poverty concentration and social problems.

2003: Major demolition and reconstruction programmes are launched, targeting large housing estates.

Though there is no formal definition of housing estates in France, many academics agree upon a classification based on their form as well as the methods used in their production; a relatively autonomous residential unit of collective buildings constructed rapidly, according to master plans that include a mix of high-rise buildings (tours) and tower blocks (barres) with local facilities (e.g. schools, shopping malls and stadiums). However, there is less agreement on the minimum threshold for defining a housing estate, which can vary from 500 units in some studies (Vieillard-Baron 2004) to 1000 units in others (Lacoste 1963). Most housing estates contain predominantly social housing (though not exclusively). The State has been heavily involved in both the production of these estates as well as the policies that have targeted them, by defining policy objectives and tools and by financing successive programmes of construction and renewal.

The term grands ensemble was first evoked to describe the Cité de la Muette. Built between 1931 and 1935 in Drancy, a northeastern suburb of Paris, historians and architects consider it to be France's first large housing estate, and indeed in 2001 it was classified as a historical monument. La Muettte comprised 1250 units and was designed by architects Eugène Beaudoin and Marcel Lods. However, it was the construction of housing estate Lochères, in Sarcelles (on the periphery of Paris) in 1954-just after the national plan Courant of 1953 - that launched the twenty-year post-war period of large-scale housing estate construction. Lochères comprised 12,368 units, representing a significant increase in the size and scale of these estates compared to the past.

\subsubsection{Suburban Housing Estates in the Paris Region: Population Growth and the Urban Renewal of Paris}

France embarked on its post-war period of housing construction as a response to a severe housing shortage. Following the damage brought about by the war, very little effort had gone into reconstruction. The Paris region was hit particularly hard. 
As a centre of industrial development, it had to accommodate a growing population comprising both domestic rural as well as international migrants, including a large flow of people from Algeria following its independence. During this time, the population of the Paris region grew from 7.2 million (1954) to 9.2 million (1968).

France's approach to constructing housing estates was enshrined in a 1958 law, which created Priority Zones for Urban Development (Zones à Urbaniser en Priorité/ZUP) and conferred power to the state to build massive, standardised social housing estates within these sites. Researcher estimates of the number of housing estates constructed throughout France during this period vary from 193 to 197 (ZUP) to 300-350, the last figure comprising 1.3 million units (Fourcaut 2006). Estates represent less than one-third of the total number of social housing units produced during this same period (Tomas et al. 2003). 26 of the 193 ZUP were built in the Paris region representing 150,000-170,000 housing units (Le Goullon 2010). These efforts were also driven by the goal of 'housing all employees' in social and collective housing and, as such, companies were major financial contributors. New government loans and subsidies were also created to fund their construction.

The conception and design of these estates were driven by a modernist vision that prevailed throughout the 1960s, inspired by the 'Athens Charter' of renowned architect Le Corbusier, and adapted to a Fordist economy and a situation of emergency housing. The grands ensembles were widely perceived as symbols of social progress, ushering residents into modernity and providing light and comfort in secure and sanitary suburbs far from the polluted inner-cities (Murie et al. 2003). It was assumed that within these estates, social groups would mix seamlessly to create new relations characterised by social harmony (Chombart De Lauwe 1965).

Aside from the availability of vacant agricultural land, there were a number of strategic reasons for building Paris's housing estates in its suburban areas beyond the periphery of the city-known in France as the banlieue. First, the 1958 urban renewal programme targeted inner-city 'slum' areas, largely made up of degraded private housing. The newly built estates of the city's peripheries served to relocate large immigrant populations of the working-class 13th and 19th districts of Paris, as well as those who had been displaced by the 1970s demolition of Paris's surrounding slums. The resulting processes of gentrification and the destruction of working-class lifestyles and networks attracted major criticism at the time (Coing 1966).

The second strategy employed sought to address land use and to control urban growth. In anticipation of Paris's impending population growth, in 1960, the Ministry of Reconstruction and Planning created a master plan (PADOG), which set directives for urban renewal, the production of housing estates and industrial decentralisation. It is within the framework of this plan that most ZUP estates were built, initially within the innermost suburbs of the Paris region to avoid overly extending the agglomeration. In 1965, as urban growth continued, a subsequent regional master plan provided a wider framework to create new development hubs located further away from Paris (15-50 kms). Today, France's social housing estates are largely concentrated within the Île-de-France region, housing $43 \%$ 
(around 150) of the estimated 350 sites built in France, including 26 of the 195 ZUPs (Fourcaut 2006).

\subsubsection{From Housing Estates to Deprived Neighbourhoods: 40 Years of Urban Policy}

The events that unfolded in Paris in 1968, and the emergence of social critics condemning these estates as a feature of a 'capitalist' mode of production (Lefebvre 1970), shattered the modernist vision that had initially inspired the grands ensembles. Furthermore, popular media had begun to expound a negative image of these places, beginning with a documentary film broadcast on national television in 1963, coining what became the notorious term 'sarcellite' - the depressive 'disease' suffered in the Lochères estate of Sarcelles. Before long, housing estates were widely condemned as sites that led to social isolation, boredom and petty crime. The rapid physical degradation of buildings that had been hurriedly constructed utilising poor-quality, prefabricated materials, only added to this diagnosis. As a result, in 1973, a famous policy circular abruptly halted the production of large housing estates above 500 housing units. This officially marked the end of the construction of large housing estates in France.

In official reports, these urban spaces were declared dysfunctional for a number of reasons. From a planning perspective, mono-functional use and a sparsity of local economic activity were seen to lead to a sense of urban isolation. The presence of open outdoor spaces that were difficult to secure led to a public perception of estates as being 'uncontrollable', despite the existence of resident ownership of these places. In addition, certain areas had become neglected due to a lack of clear boundaries between public and private space and resulting uncertainty over who was responsible for their management.

These perceptions were strongly influenced by emerging representations of the housing estates of the banlieue as dangerous, following periodic violent incidents that occurred in 1971 and 1981 in the suburbs of Lyon and Paris. Following these, the prevailing future image of these places seemed to have been decided: the 'deprived neighbourhoods' label entered public discourse, and successive urban policies have since focused on solving what is now framed as the 'banlieue problem'.

While these representations of the Paris banlieue estates do prevail, they have been criticised by many academics, who caution against reducing these sites to incidents such as the November 2005 riots. Recent analysis frame these actions as a plea from excluded young people to be included in French society (Moran 2017), bringing to light the broader, systemic context within which the concentration of poverty and ethnic groups is grounded. These representations have been reinforced in the wake of the multiple terrorist attacks committed in France: Islamophobic sentiment appears to have increased, making the large number of North African and 
Muslim people residing in these estates particularly vulnerable to discrimination (Moran 2017; Mondon and Winter 2017). This compounds further their spatial exclusion and, in some opinions, their exclusion from Republican narratives of the citizen.

Another assumption that is highly debated throughout Europe - and one that underpinned many of the renewal programmes that followed-is that a concentration of low-income and unemployed people leads to negative 'neighbourhood effects' that exacerbate their exclusion from society. Symptoms of these effects were presented as school failure, chronic unemployment and poverty, but also petty crime, conflict and drug trafficking. In the 1970s, sociologists had already begun to object to the hasty connections being made between the built environment and social problems, pointing out that such problems existed throughout society, and in all kinds of spaces (Huguet 1971).

Against this background, France's City Policy (Politique de la ville) has, since 1983, implemented a series of programmes that combine socio-economic measures with the restructuring of the built environment and public space. The City Policy targets a selection of deprived neighbourhoods, classed as priority neighbourhoods. While not all of neighbourhoods consist solely of housing estates, a number of the more specific urban restructuring programmes that have been implemented since the 1990s through the framework of this policy, have de facto targeted housing estates. Throughout this period and until the early 2000s, a soft rehabilitation that sought to avoid displacing workers was pursued. This was largely in response to the criticism received over the major displacement caused by the slum demolitions of the 1970s in Paris.

Like in many other European countries, social mixing through housing diversification remains a central objective of these programmes (Kleinhans 2004). Described as a means by which to reduce levels of poverty concentration and to prevent urban social enclaves, social mixing is primarily implemented through the demolition of high-rise social housing buildings, which are in many cases replaced by private dwellings in a bid to attract middle-class residents. In theory, demolition is undertaken according to the 'one to one' principle - one unit rebuilt for every unit demolished - so that the absolute number of social housing units remains stable.

The City Policy was significantly revised in 2014. The current policy runs until 2020 and includes the following components:

- City contracts between the state, regions and cities, which set out concrete actions that are to be pursued in each priority neighbourhood according to three central pillars: housing, living conditions and urban renewal; social cohesion; and economic development and employment. To date, 438 contracts targeting 1292 priority neighbourhoods (QPVs) have been signed.

- Urban renewal programmes. Included as part of the city contracts, these programmes focus on transforming the urban form and on diversifying housing tenure. They concern 400 priority neighbourhoods. 
- The extension of a specific legislative arrangement initiated in 2000 , which aims to create social mixing by requiring municipalities with less than $25 \%$ of social housing to take measures to reach this target.

Finally, three specificities of French urban policy have greatly influenced housing estate policies and planning. First, despite a major decentralisation process in 1982 and an increase in private funding since 2014, policies targeting housing estates remain strongly driven by national programmes. Second, the French concept of social housing is universal, rather than being reserved exclusively for low-income people. Third, the state's continued pursuit of social mix policies goes hand in hand with the value (and rhetoric) of 'territorial equality', in spite of ongoing criticism of these approaches. Area-based policies presented as a means to reduce the 'gaps' between territories allow public authorities to tackle ethnic concentration without naming it as such (Escafré-Dublet and Lelévrier 2014).

\subsection{Location, the Built Environment and Demographic Shifts in Housing Estates in the Paris Region}

The Paris region has 12 million inhabitants, of which 2.2 million live within the city of Paris. Prior to 2016, it was made up of eight departments, with four departments located each in both the region's first and second rings (Fig. 14.1). The official creation of the 'Greater Paris Metropolis' in 2016 amalgamated Paris and three surrounding departments, containing the inner suburbs of the region (Seine-Saint-Denis, Hauts-de-Seine and Val-de-Marne), and comprising 6.9 million inhabitants.

\subsubsection{Housing Estate Locations Reflect a Historical Regional Divide}

The spatial distribution of social housing (Fig. 14.2) and of renewed housing estates (Fig. 14.3) is linked to historical regional structures and policies. The first visible trend is the concentration of this type of housing in the northeastern part of the region (17.1\% of the region's overall social housing, $34.5 \%$ of all housing estates in Seine-Saint-Denis), where poverty and unemployment rates are highest. This reflects a historical social division between the East and the West of the region. While the East has traditionally been an industry hub for trade work, mainly housing the working class and a large number of immigrants, the West is made up of large residential areas and ample green space and has historically been home to the middle and upper classes. Other major housing estate sites are situated along the Seine river in close proximity to the motor industry (South and West), and are dispersed across less urbanised areas located 20-40 kms from Paris. 


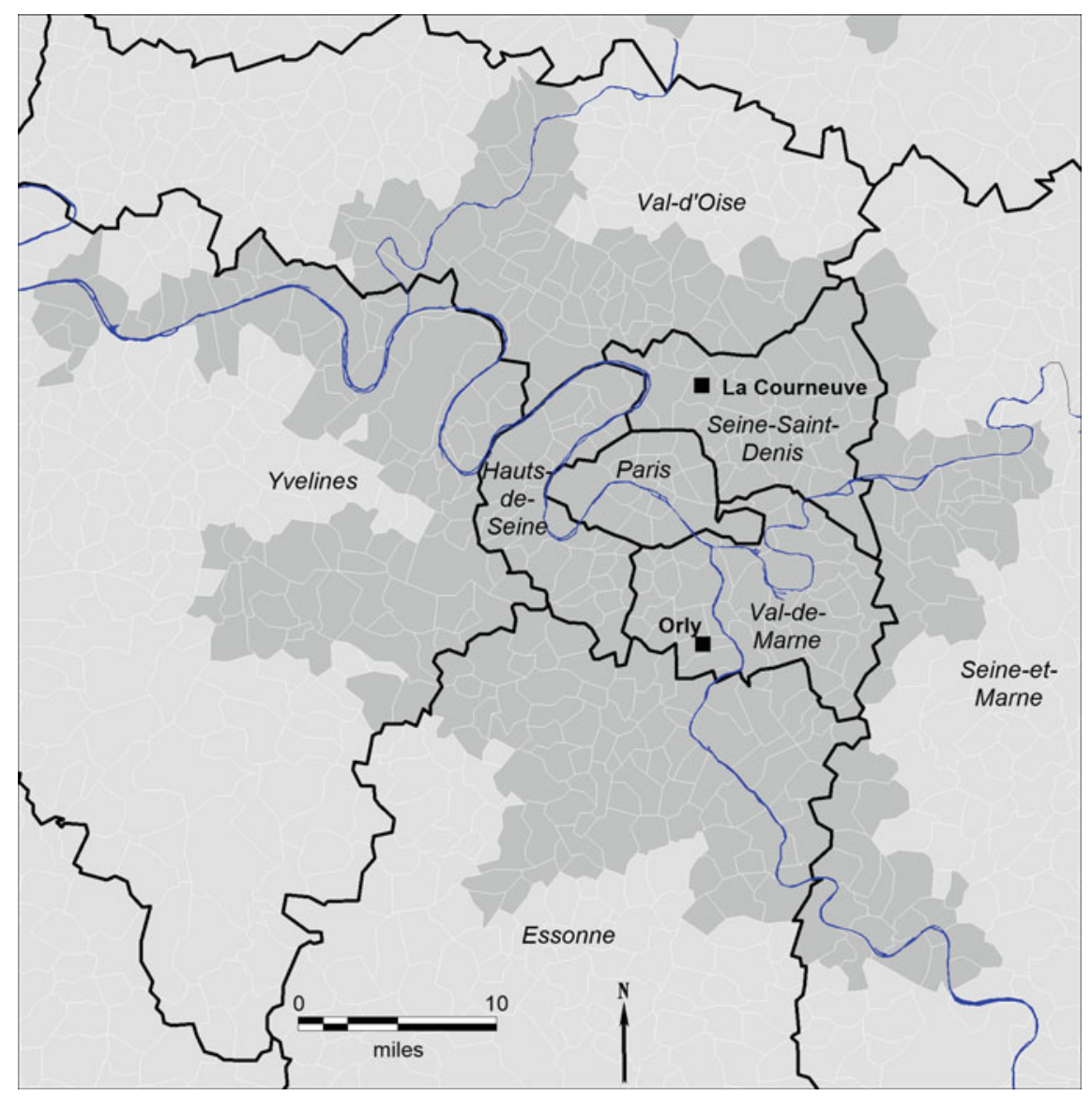

Fig. 14.1 Departments in the Ile-de-France region and location of Orly and La Courneuve municipalities

The traditional narrative regarding the demographic shifts occurring within housing estates states that an initially socially mixed population was gradually replaced by a majority of people in situations of immigration and unemployment. This demographic shift was encouraged by homeownership programmes established by the government as part of its 1977 housing reform policies. The programme provided affordable loans and individualised housing assistance. Following the resultant mass-departure of middle-income residents from housing estates all over the country, social housing was freed up for migrants and their families-who up until this point had been living in slums or temporary dwellings. Although in 1974, immigration laws had to curtail the intake of new migrants, they made allowances for families to be reunited. As such, newly arrived family members joined their relatives in homes within these vacated estates. 


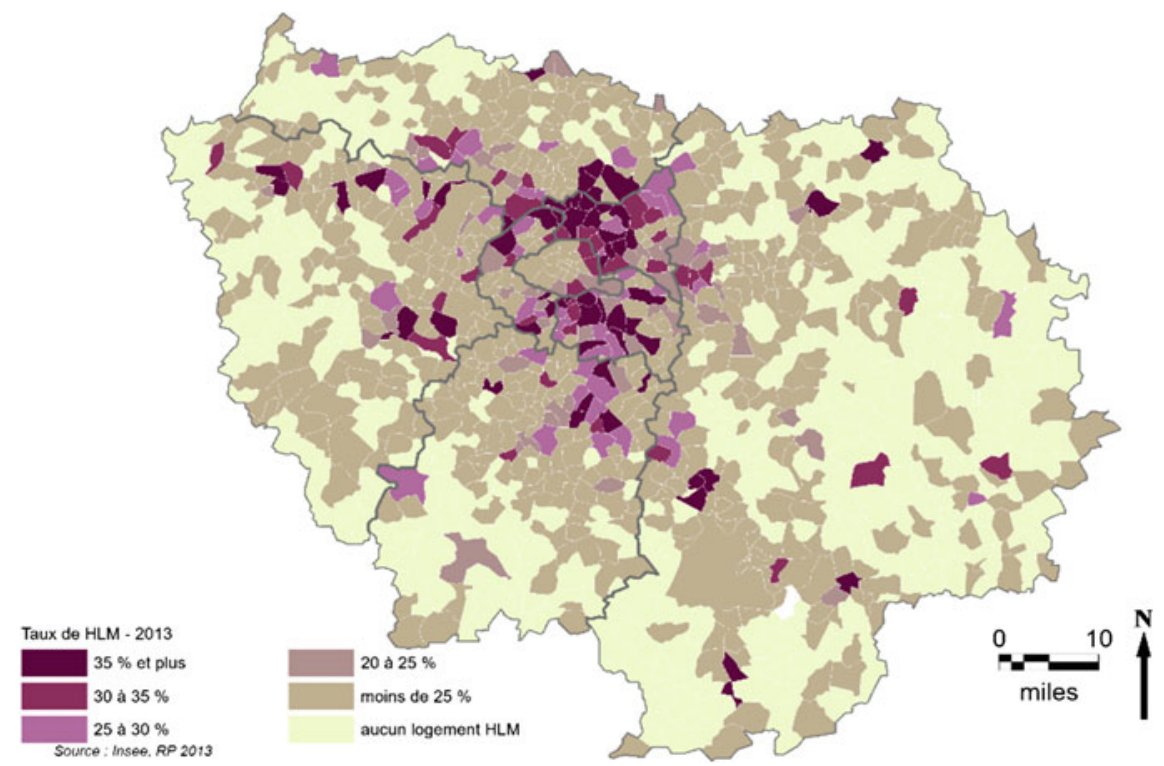

Fig. 14.2 Percentage of social housing (HLM) across municipalities of the Paris Region. Source Insee, Census 2013, IAU

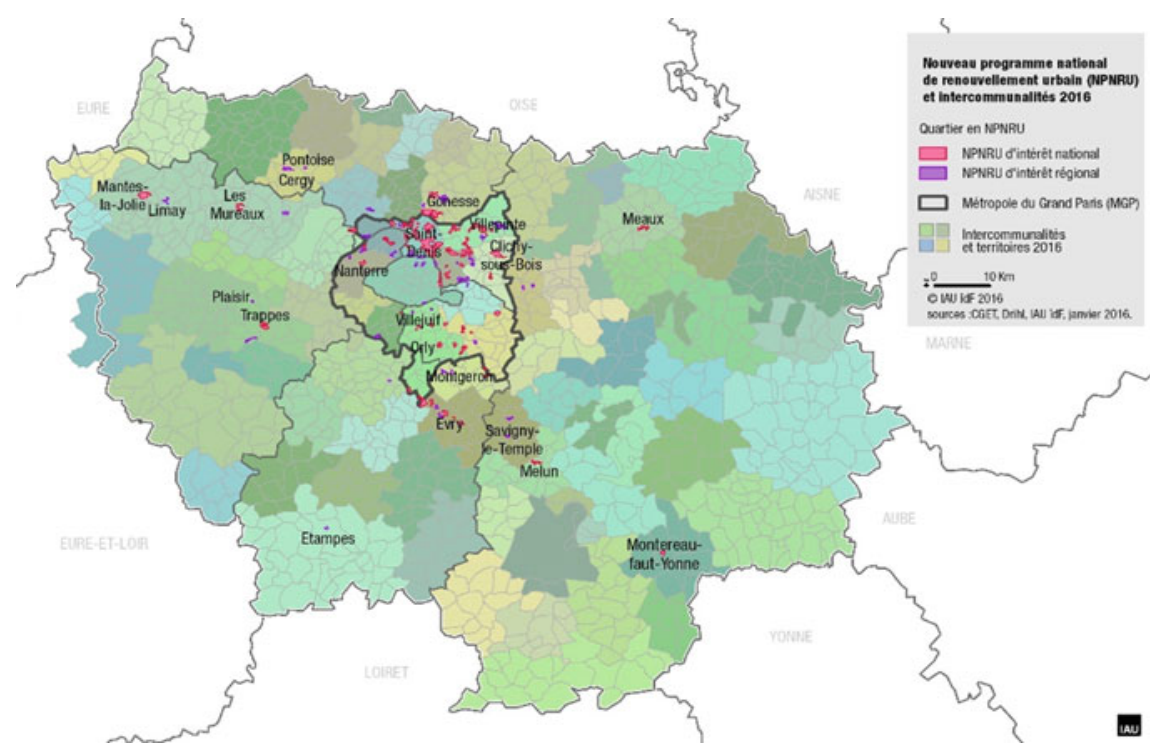

Fig. 14.3 Renewed neighbourhoods in the Paris region. Source General Committee for territorial Equality (CGET), IAU, 2016 
Despite this prevailing narratives, close examination of the data reveals that many of the estates that are now being targeted by programmes of demolition and reconstruction did not undergo such a demographic transformation, but have always housed low-income and migrant families. These families were relocated from degraded sites in Paris or worked in local companies that provided social housing support. A more significant demographic shift was in the impoverishment of many families already living in such estates as a result of economic changes. The 1974 oil crisis set in motion a process of economic precariousness and escalating unemployment. Examination of two large housing estate sites located in Orly and La Courneuve provides further insight into these processes.

\subsubsection{Internal Segmentation in Two 1960s Housing Estates: Orly and La Courneuve}

Located in medium-sized municipalities within Paris's first suburban ring, the 4000 housing estates in La Courneuve and the large housing estate in Orly share many common features. They were both built during the 1960s, and both have a large number of housing units (4900 in the La Courneuve estate, 5492 in Orly), representing at least half of the total population of each municipality, respectively. This translates into a population of 15,251 people in the 4000 and 13,298 in Orly's large housing estate (according to 2006 census data). Both sites are less than half an hour from the centre of Paris by train and are close to international airports, regional economic centres, basic amenities and large shopping centres. The architecture and planning of both are typical of a modernist conception of housing estates. A large number of high-rise buildings (in La Courneuve, 35 high-rise buildings ranging from 4 to 26 floors; and in Orly, various buildings ranging from 4 to 16 floors) represent what was conceived as a whole 'unit' of life, incorporating green spaces, and separating pedestrian areas from those of cars (Fig. 14.4).

Both sites housed those who had been displaced from the city centre by Paris's 1958 urban renewal programmes, people repatriated from Algeria following its 1962 independence, and those who worked in nearby factories or the Orly airport. They were initially managed remotely by the Seine public office before oversight was transferred to local public housing offices in the 1980s.

Internally, both estates are segmented, contradicting standard visions of housing estates as homogenous places. In Orly's housing estate, many of the poor and immigrant households relocated from Paris were provided housing of inferior quality to mainstream social housing because they could only afford low rents. On the same sites, workers from the nearby international airport had access to more standard social housing buildings. Inequalities in rent and in quality introduced an internal social division - today the site consists of five different sub-sectors, according to the funding structure, architectural design, building quality and rent levels. Many of the taller buildings (4-16 stories) are concentrated towards the heart 

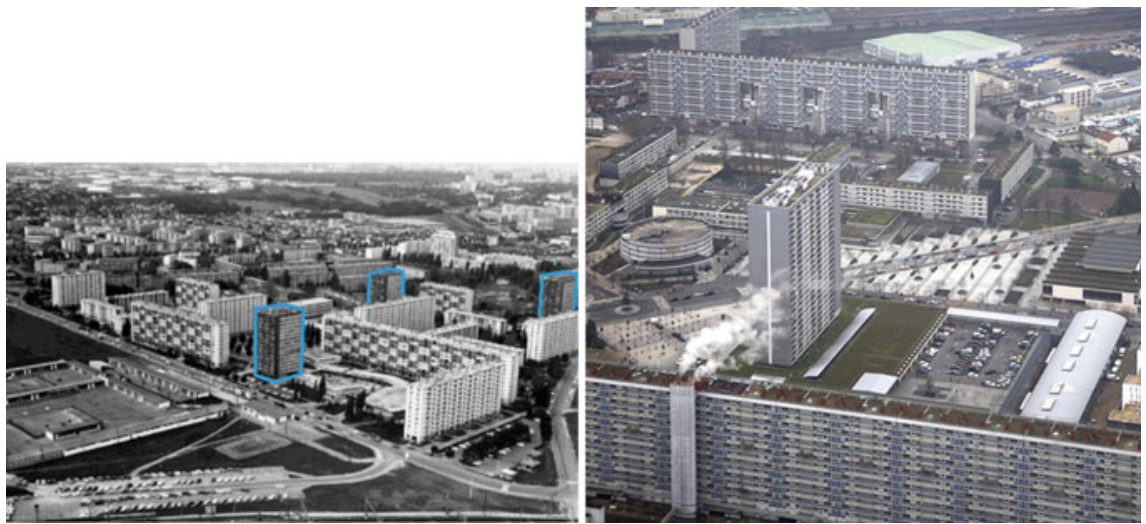

Fig. 14.4 Built environment and urban form of large housing estates Orly and La Courneuve, 1960s. Source Orly (city) and La Courneuve (blog. 40 quartiers, website, see La Courneuvephotojpg)

of the estate. They were rehabilitated in the 1980s and are currently in the process of being demolished.

In La Courneuve's 4000, the housing estate comprises two complexes in the north and the south. The tallest, poorest quality buildings with the largest apartments and the cheapest rents are concentrated in the south, while the north comprises smaller buildings, has a more residential setting, and is closer to the city centre. Unsurprisingly, it is the buildings within the southern area that have been targeted for demolition under urban renewal programmes (Fig. 14.5).

This internal spatial differentiation demonstrates how France's housing estates are the products of multiple housing interventions catering to diverse categories of the population. Different entities including the State, municipality and private companies have set allocation quotas that determine access to social housing, resulting in the presence of a variety of social groups in any given estate, often with
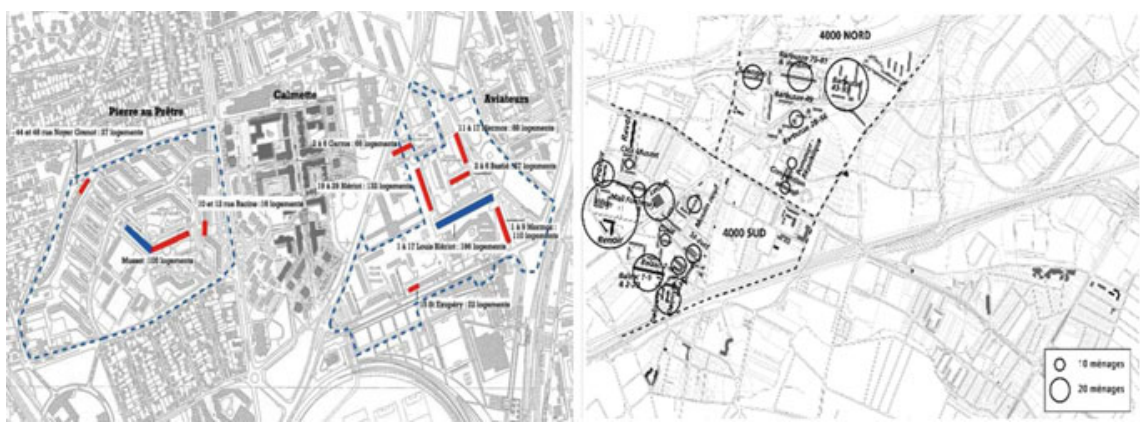

Fig. 14.5 Sub-sectors and demolitions (2003 urban renewal) of large housing estates in Orly and La Courneuve. Source Relocation board, April 2010; City/Valophis housing corporation 
divergent residential trajectories. For those middle-class residents who found their way into the estates through their respective companies, their stay was typically one of transition within the residential trajectory. For low-income groups, in contrast, the housing estate tended to represent the end of their residential trajectories, becoming their permanent residence (Chamboredon and Lemaire 1970).

\subsection{Social Change: Increasing Social Gaps and Spatial Differentiation}

The official category 'priority neighbourhoods' is not an exactly synonymous with 'housing estates' and the data available on these varies from programme to programme. Despite this limitation, by drawing from data at a regional level, and using the two housing estate case studies of La Courneuve and Orly, we are able to gain insight into the main trends taking place within these housing estates.

\subsubsection{A Growing Concentration of Large Families and Immigrants in Northeast and Peripheral Areas of Paris}

In 2006, those living within the 157 'priority neighbourhoods' (ZUS's) of the Paris region represented $11 \%$ of the regional population (above the national French average of 7.2\%) (Insee-Première 2010). When this category was extended in 2014 to cover 272 neighbourhoods, ZUS's accounted for 1,570,000 residents, or $13 \%$ of the regional population.

The most recent population data available (from 2006 and 2012) from Île-de-France reveals an increasing social gap between these priority neighbourhoods and the rest of the urban unit. In 2006, these neighbourhoods comprised a higher proportion of immigrants (36.2 vs. $22 \%$ in their urban units), half of them originating from Maghreb countries. They also contained twice as many large households (defined as five or more people) and had a higher proportion of young people alongside a lower proportion of elderly people (Table 14.1). However, figures on ethnic concentration would likely jump significantly if 'descendants of immigrants' were taken into account. A 2012 national survey found that an average of $52 \%$ of priority neighbourhood residents originated or had a parent that originated from another country, compared to just $22 \%$ of the population in the surrounding agglomerations (ONZUS 2012).

There is a significant income gap between people living in priority neighbourhoods and the surrounding urban unit. Within the Paris region, a recent study shows a higher median living standard (1140 €/month) and a lower percentage of people living under the poverty line compared with priority neighbourhoods located in 
Table 14.1 Sensitive Urban Zones (ZUS), 2006: comparison of France/Paris region (RIF) and ZUS/Urban environment (UU, urban units)

\begin{tabular}{l|l|l|l|l}
\hline Indicators & France ZUS & France UU & RIF ZUS & RIF UU \\
\hline Number of ZUS & 751 & & 157 & \\
\hline Total population & $4,361,000$ & & $1,278,300$ & \\
\hline People $<20$ & 31.6 & 24.9 & 32.5 & 25.7 \\
\hline People $>60$ & 14.8 & 19.8 & 11.6 & 16.6 \\
\hline Foreigners & 17.5 & 8.2 & 23.0 & 13.3 \\
\hline French (acquisition) & 10.2 & 5.9 & 13.2 & 8.7 \\
\hline Single-parent family & 25.7 & 15.8 & 24.7 & 16.4 \\
\hline Households 5 and + & 12.7 & 6.6 & 15.4 & 7.9 \\
\hline Home ownership & 20.0 & 47.0 & 19.5 & 44.6 \\
\hline Flats 5 rooms and + & 16.9 & 26.2 & 11.3 & 18.9 \\
\hline Vacant flats & 6.7 & 6.3 & 5.6 & 6.3 \\
\hline
\end{tabular}

Source Census 2006 (annual estimation surveys) - Insee Première, 2010

other regions of France. However, there are significant differences between priority neighbourhoods and the rest of the Paris region: $710 € /$ month below the region's median living standard, with $37 \%$ of people living under the poverty line in priority neighbourhoods (Insee-Analyses 2017).

Further analysis reveals patterns of segregation across the Paris region, as demonstrated (Table 14.2) by average foreign population numbers (1999) and income levels (2004). The data illustrates two marked discrepancies: poor housing estates in disadvantaged areas within the inner suburbs, in addition to pockets of poverty within more affluent outer suburban areas. In the housing estates of Paris's northeastern departments (Seine-Saint-Denis, Val d'Oise), foreigners and low income households are overrepresented. Meanwhile, the gap between these same indicators in some housing estates in the region's more affluent West (Yvelines) is significantly more pronounced: 28.5 versus $8.9 \%$ for foreigners and 9,990 versus $22,275 €$ in the median income.

A recent study identified six types of neighbourhoods among the 272 deemed 'priority' in the Paris region, based on surface area, population and income data (Insee-Analyses 2017). Two of these types correlate with housing estates. 'Large neighbourhoods of vulnerable families located far from Paris' (type D) tend to be located 20-30 kms from Paris and have the poorest standard of living - around 43\% of their population live under the poverty line. These areas are excluded from the new Greater Paris metropolis, and this will likely widen existing gaps. 'Historical City Policy neighbourhoods' (type E) include renewed neighbourhoods. The case study housing estates in Orly and La Courneuve fall under this category. Approximately $39 \%$ of the population of type E neighbourhoods live under the poverty line (Table 14.3). These two categories combined comprise 73 large housing estates-more than $55.3 \%$ of the population of Paris's priority neighbourhoods. 
Table 14.2 Foreign population and income levels in housing estates (renewed neighbourhoods) and suburban departments of the Paris region

\begin{tabular}{l|l|l|l|l}
\hline & \multicolumn{2}{l}{ Housing estates (ANRU) } & \multicolumn{2}{l}{ Departments } \\
\cline { 2 - 5 } & $\begin{array}{l}\text { Median } \\
\text { income/UC/ } \\
\text { year (€) }\end{array}$ & $\begin{array}{l}\text { Foreign } \\
\text { population } \\
(1999)(\%)\end{array}$ & $\begin{array}{l}\text { Median } \\
\text { income/UC/ } \\
\text { year }(€)\end{array}$ & $\begin{array}{l}\text { Foreign } \\
\text { population } \\
(\%)\end{array}$ \\
\hline Hauts-de-Seine & 12,713 & 19.7 & 22,088 & 11.5 \\
\hline Seine-Saint-Denis & 9,096 & 28.1 & 13,719 & 18.9 \\
\hline Val-de-Marne & 11,850 & 17.6 & 18,936 & 11.8 \\
\hline Seine-et-Marne & 10,092 & 19.4 & 18,800 & 7.7 \\
\hline Yvelines & 9,900 & 28.5 & 22,275 & 8.9 \\
\hline Essonne & 11,323 & 19.3 & 20,272 & 8.2 \\
\hline Val d'Oise & 9,923 & 22.8 & 18,066 & 10.8 \\
\hline Region & 10,432 & 23.4 & 19,402 & 11.9 \\
\hline
\end{tabular}

Source DGI 2004; RGP 1999

Table 14.3 Comparison of two types of priority neighbourhoods in the Paris region

\begin{tabular}{l|l|l|l}
\hline Indicators & Type D & Type E & $\begin{array}{l}\text { Priority regional neighbourhoods } \\
(\mathrm{QPV})\end{array}$ \\
\hline Number & 31 & 42 & 272 \\
\hline Population & 137,000 & 731,000 & $1,547,000$ \\
\hline$\%$ of the pop. QPV & 9 & 47 & $(13 \%$ region pop. $)$ \\
\hline Households 5+ (\%) & 21 & 21 & 19 \\
\hline Annual median income & 28,800 & 31,100 & 30,900 \\
\hline Welfare beneficiary (\%) & 68 & 65 & 64 \\
\hline $\begin{array}{l}50 \% \text { income = welfare } \\
\text { benefits (\%) }\end{array}$ & 79 & 70 & 67 \\
\hline $100 \%=$ welfare benefits $(\%)$ & 47 & 44 & 41 \\
\hline Poverty rate (\%) & 43 & 39 & 37 \\
\hline
\end{tabular}

Source Filosofi 2012; Insee Analyses 2017

\subsubsection{Poverty Concentration Enhanced by Parallel Trajectories of Mobility and Long-term Tenancies}

Recent data demonstrates that the concentration of poverty and immigrant populations within housing estates is increasing rather than decreasing. A significant limitation of this data is that while it measures how spatial concentration has evolved, it ignores the processes that produce this concentration and the diverging trajectories of the populations concerned. Examining these processes, rather than the ratios, reveals a different picture of the evolution of these estates.

For instance, census data on increasing poverty does not reflect population turnover. A 2005 national survey reveals that in $1999,40 \%$ of priority 
neighbourhood residents had moved to the neighbourhood within the past 10 years. Studies suggest that those recently arrived residents are younger and have lower incomes than those who are leaving. There is a causal link between this process of mobility (where people move in and out of these neighbourhoods) and that of impoverishment. This mobility raises additional questions about interpreting the causes of changes in poverty levels within these estates - how do we determine the contribution of policies to such changes? How do we evaluate policies that may have positive effects on people's individual trajectories but do not alter the spatial concentration of poverty within housing estate sites?

In parallel, solitary elderly people are becoming trapped - or choosing to remain -in large apartments, even if their incomes have long since decreased. In 2003, when buildings containing large apartments were designated for demolition to disperse families across renewed housing estates, the actors involved were surprised to discover a high proportion of elderly residents living in large apartments (Lelévrier 2013a). They were long-standing tenants who simply did not have enough resources to leave the neighbourhood, or who wanted to stay and hold onto their flats after their children had left. The proportion of elderly residents remaining in these housing estates defied expectations. Even though France's population as a whole is undergoing an ageing process, the discourse surrounding housing estates in the media and amongst officials focuses predominantly on young people. As such, these elderly residents have been less visible. In Orly, this ageing process has become significantly more pronounced since 1990 (Table 14.4). Greater awareness of the location of elderly residents would improve how local needs are defined and what services and supports are put in place to meet them.

\subsection{Spatial and Social Effects of Policies and Planning Strategies}

While the data suggests that segregation has not decreased, 40 years of public policies have changed the urban form of a great number of housing estates in the Paris region and, as such, have affected the spatial and social configuration of this segregation. The first 25 years of these policies were devoted to rehabilitation, infrastructure improvement and socio-economic measures, most of them targeting children and unemployed people. However, the greatest social impact has been that of urban restructuring and housing diversification through urban renewal programmes.

The first urban renewal programme of the Paris region has not yet been completed. However, in its first decade (2003-2013), 23,000 social housing units have already been demolished (out of a total 38,200 planned demolitions); 10,100 new social housing units have been built (of 20,700 planned) and 5,700 private dwellings have been developed (of a planned 21,600). At the end of this first stage, $10 \%$ of the housing stock of targeted estates has been renewed. Ten years into this 
Table 14.4 Characteristics of population change, Orly and La Courneuve, 1982, 1990, 1999

\begin{tabular}{l|l|l|l|l|l|l|l}
\hline Indicators & $\begin{array}{l}1982 \\
\text { Orly }\end{array}$ & 1990 & 1999 & $\begin{array}{l}1982 \\
\text { Courneuve }\end{array}$ & 1990 & 1999 & $\begin{array}{l}1999 \\
\text { ZUS-ANRU } \\
\text { region }\end{array}$ \\
\hline Population & 19,458 & 17,203 & 14,413 & 13,246 & 12,293 & 15,553 & \\
\hline $\begin{array}{l}\text { People/ } \\
\text { household }\end{array}$ & 3.24 & 2.98 & 2.76 & 3.54 & 3.44 & & \\
\hline Under 20 years & 36.5 & 33.1 & 30.8 & 40.6 & 37.9 & 36.2 & \\
\hline Above 60 years & 8.7 & 12 & 15.4 & 7.9 & 8.7 & 11.7 & \\
\hline Households 6+ & 10.9 & 9.1 & 7.0 & 20.2 & 15.6 & 12.6 & 8.7 \\
\hline $\begin{array}{l}\text { Foreign } \\
\text { population }\end{array}$ & 19.3 & 19.5 & 15.7 & 20.8 & 28.7 & 26.0 & 23.4 \\
\hline Unemployed & 15.8 & 17.7 & 24.7 & 27.5 & 29.4 & 28.3 & 21.3 \\
\hline $\begin{array}{l}\text { Without diploma } \\
55.9\end{array}$ & 44.8 & 39.2 & 60.8 & 50.4 & 39.4 & 31.1 \\
\hline Single-parent & 16.7 & 16.4 & 19.8 & 15.6 & 19.1 & 17.5 & 15.8 \\
\hline $\begin{array}{l}\text { Employees } \\
\text { clerical } \\
\text { workers) }\end{array}$ & 39 & 36.6 & 38.6 & 39.8 & 36.6 & 38.3 & 21.7 \\
\hline $\begin{array}{l}\text { Workers } \\
\text { (Blue-collar) }\end{array}$ & 43.9 & 44.9 & 37.4 & 41.0 & 45.8 & & 30.1 \\
\hline $\begin{array}{l}\text { Median income/ } \\
\text { UC (2002) }\end{array}$ & & & 10,428 & & & 7,333 & \\
\hline
\end{tabular}

programme, some general patterns of urban and social effect can be identified, with varying local trajectories.

\subsubsection{Improvement of the Built Environment and the End of Housing Estates}

Significant public investment has been injected into the infrastructure of $1960 \mathrm{~s}$ housing estates through successive public policies. The condition of the urban environments in which these estates are located has also improved through regional development efforts, with better transport and access to local facilities.

A 2013 evaluation found that the public space of renewed housing estates was of higher quality and more sustainable (CES-ANRU 2013). These estates have been transformed from a functional, modernist design into a postmodern conception embodying new urbanism principles. These principles include connecting roads, a mixture of car and foot traffic, subdivision of plots of land to build smaller residential units (40-150 dwellings up to six stories high), public squares and streets designed as places of encounter with mixed functions (e.g. shops, services) and tenure mix. The French 'résidentialisation' process has implemented defensible space theories, gating-off new and existing buildings with the purpose of reducing 
vandalism, separating public and private space (for easier management) and creating housing that looks more 'private and residential'. The underlying assumption driving this urban design is that such changes will improve the image of the area, attracting more affluent newcomers and promoting greater social diversity. This urban transformation leading to more ambiguous and controversial effects (Fig. 14.6).

Urban change is most visible in the large housing estates of the 1960s, which have been subject to demolition and reconstruction since the 1980s. In the La Courneuve 4000 estate, seven buildings comprising 1500 housing units have been demolished since 1986, representing $37.5 \%$ of the housing stock. In the Orly case, urban renewal began in 1976, when the oldest transitory buildings were demolished. From 1976 to 2013, nine buildings containing 1631 housing units were replaced by a mix of social (800) and private (633) housing units. By 2020, 30\% of the housing stock will have been renewed. After 40 years of urban renewal processes, it can be said that the 'large housing estate' no longer exists as an urban form.

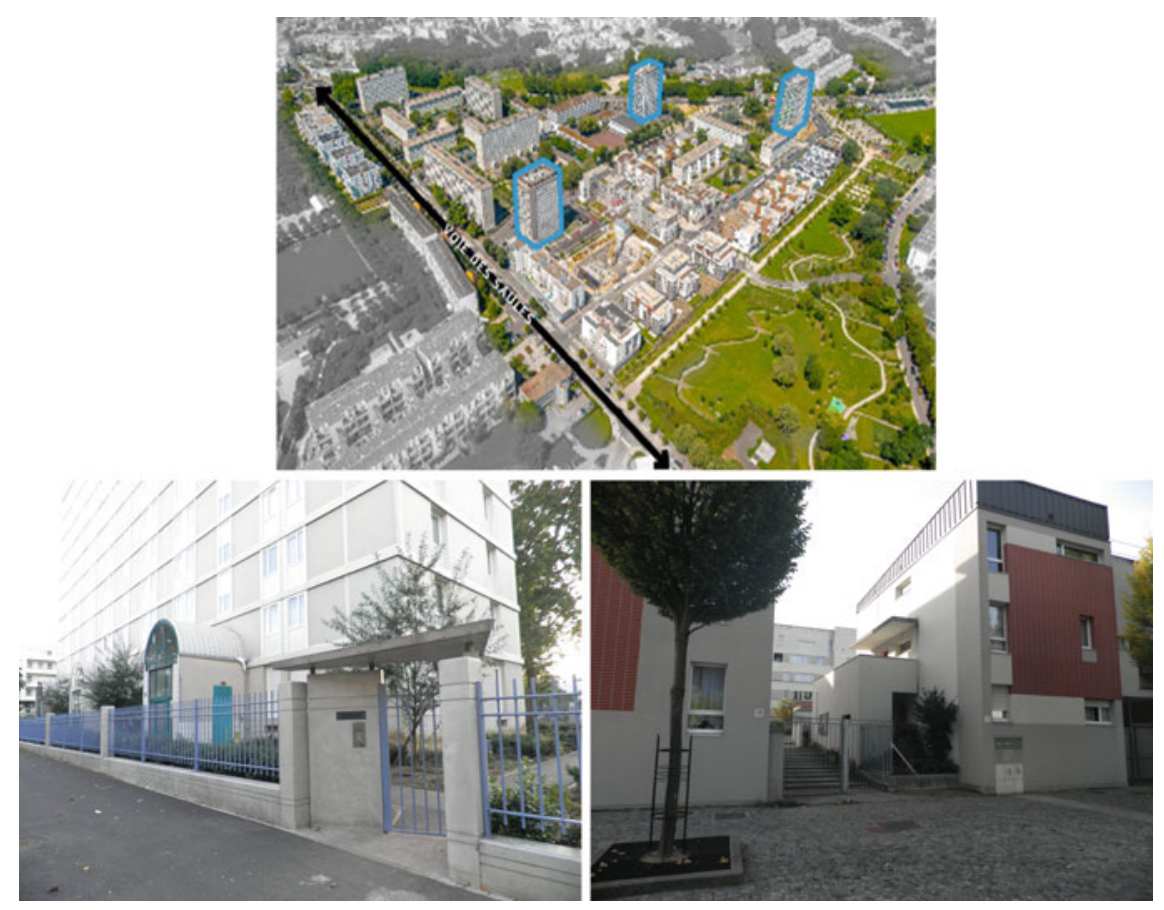

Fig. 14.6 'Gating' of existing buildings and new housing developments in Orly 


\subsubsection{The Paradoxical Effects of Urban Renewal}

France's City Policy and renewal programmes aim to improve living standards by reducing segregation and promoting the 'return' of middle-class groups into spaces in which poverty is concentrated. However, after ten years of urban renewal, public evaluations find that while these efforts have transformed the built environment, the socio-economic living conditions of the populations that these policies have intended to benefit have remained relatively unchanged, and poverty remains as concentrated as ever (Cour des Comptes 2012; CES-ANRU 2013).

We have identified four main reasons for this trend. First, the changes brought on by area-based policies have been marginal in comparison to the impacts of wider urban social and economic transformation. The economic situation of low-qualified residents of the housing estates in Paris's old industrial areas remains dire after many companies have closed down, leading to widespread job loss. Poverty levels have increased among social housing residents, both within but also beyond housing estates. Second, between 2003 and 2013, social measures and support for local initiatives have been drastically reduced in favour of interventions in the built environment. Third, even when renewed estates have managed to attract more affluent households into new developments, the number of households remains too marginal to alter the social structure and to affect poverty concentration levels. Finally, urban renewal seems to have produced the 'paradoxical effects' (Blanc 2010; Lelévrier 2013b) of reconcentration through relocation. This finding is explored in more depth below.

\subsubsection{A Reconcentration of Relocated Households}

Rather than being dispersed across the Paris region, residents of demolished buildings have been primarily relocated within the same neighbourhoods. According to national evaluation, $60 \%$ of relocated residents remained within the same neighbourhood and $89 \%$ within the same municipality. This national trend can be explained in part by the preference of many residents to remain in their neighbourhoods, demonstrating an attachment to these outwardly stigmatised areas. However, these figures are also representative of residents' limited housing options. The poorer and older a household, the more likely its residents will be relocated into the same type of building and neighbourhood. This 'reconcentration phenomenon' (Lelévrier and Noyé 2012) is particularly pronounced within the Paris region.

In La Courneuve, $93.4 \%$ of residents of demolished buildings remained in the same municipality, and $73 \%$ continued to live in the poorer, southern part of the estate. The housing choices available to these relocated households were extremely limited $-78.8 \%$ of them lived on less than $20 €$ a day, and more than half were large immigrant families. Few other apartments in the region were large enough, and low enough in rent, to meet their needs. Furthermore, social housing corporations from 
neighbouring municipalities were often reluctant to host families relocated from a once stigmatised housing estate.

In Orly, $98.5 \%$ of those who were relocated remained in the same municipality, and $50 \%$ within the same sub-sector of the housing estate. Compared to $\mathrm{La}$ Courneuve, relocated households were much smaller in size and also older (38\% were aged over 60 vs. $17 \%$ nation-wide) and had higher incomes (only $34.4 \%$ lived on less than $20 €$ per day). As a result, it was easier to disperse households among the different sub-sectors of the estate and beyond.

\subsubsection{New Housing Developments: Opportunities for Upper Working-class Residents}

New housing developments were intended to promote social mixing by attracting more affluent residents. The available data and local surveys highlight two main trends within the Paris region in this regard. First, there have been far fewer private developments than planned, and where they have been created, such developments tend to take the form of small apartments built on the fringes of existing housing estates. Second, although less visible in the data, the internal social configuration of housing estates is changing. Newcomers in private housing do tend to earn higher incomes than former residents, indicating that some form of social mixing is taking place. Their social profiles stand in contrast to the majority of residents-relatively small-sized households, young couples and families with jobs and average salaries. However, many of these 'newcomers' are, in fact, existing residents, who were already living in the neighbourhood or within social housing in another part of the same municipality (Lelévrier 2013b). Furthermore, local surveys find that approximately $50 \%$ of these private housing residents are immigrants or the descendants of immigrants. For these residents, their entry into private residency can be considered a step forward in their housing careers. For local officials, it can be seen as a form of internal social mixing, though it is reserved for the estate's most privileged. From the perspective of poverty reduction, this internal reconfiguration has no effect on the absolute poverty levels of the neighbourhood and actually reinforces internal segregation and differentiation between buildings with different tenures and social profiles.

\subsubsection{Impoverishment in La Courneuve, Urban and Social Fragmentation in Orly}

Urban renewal in the La Courneuve and Orly housing estates reveals two distinct trajectories as a result of differing local contexts and approaches. 
In La Courneuve, urban renewal was not able to alter the course of continued impoverishment nor remove the negative stigma associated with housing estates. Poor households and large migrant families have been relocated into other degraded high-rise buildings, or into new social housing programmes, with two-thirds concentrated within three sub-sectors of the estate. These household trajectories reveal a pattern of displacing stigmatisation and poverty from one demolished building to another, and as such, outsiders have been discouraged from moving in, despite substantial renewal efforts.

Prior to renewal, Orly's population was already diverse, containing a large number of medium-sized apartments. The local strategy pursued by both the municipality and the social housing corporation promoted social mixing by offering improved public services and opportunities for existing residents to upgrade their residences. This encouraged them to remain in the neighbourhood even if other options were accessible to them. A survey conducted demonstrated that new affordable home ownership programmes attracted young adult children of local Algerian families, who tended to be more highly educated and employed. This resulted in social diversity within the renewed estates (though not ethnic diversity). However, as of 2006, the average income of those living within housing estates had not increased, despite increases within the municipality of Orly as a whole. A 2011 survey also revealed wide gaps in poverty rates between the five different sub-sectors of the estate, ranging from $25 \%$ in renewed areas compared to $40 \%$ in remaining areas.

In addition to urban de-concentration policies, actions have been undertaken to promote training and employment, to prevent crime and to better manage public space. However, the funding for these important initiatives is low and precarious, and the small local associations that implement them are not able to respond to the challenges described. Furthermore, a failure to formally recognise ethnic discrimination leads to strong feelings of injustice (Hancock et al. 2016).

Socio-economic policies have been implemented differently in the respective municipalities, according to their financial resources-illustrating how housing estates are embedded within a local context and within structural regional inequalities. For example, the entire Seine-Saint-Denis department, in which La Courneuve is housed, has a high concentration of poverty. In 2009, the mayor of La Courneuve filed a complaint to the HALDE (France's supreme authority to fight discrimination) against territorial discrimination. He sought to alert public authorities to the damaging effects of the stigmatisation of housing estates and the injustice being inflicted as a result of inferior public services and discriminatory employment processes (Hancock et al. 2016). Orly, on the other hand, is located in a more privileged department. These strong regional and territorial inequalities are not taken into account in most analyses, and yet these findings make a strong case for redistribution and positive discrimination. 


\subsection{Conclusion}

When constructed in the 1960s, France's housing estates were conceived as an urban and social utopia, embodying ideals of modernity and decent living standards. Yet, by the 1970 s, they were rejected as sites seen to produce urban dysfunction and social isolation. While initially conceived as socially mixed places in which different social groups would be able to live in harmony, over time, France's grands ensembles came to symbolise 'ghettos' that concentrated poverty and crime and reflected the failure of the French Republican model (Sala-Pala 2005).

To address what was now considered a public problem, between 1977 and 1990, public authorities implemented a lightweight programme to renovate buildings and common spaces, accompanied by micro-social interventions addressing school failure, access to employment and delinquency. At this stage, these 'problems' were considered to be temporary, and it was thought that testing a few policies in a small number of estates would provide a formula for remedying them. One of the main reasons for pursuing this approach was to avoid a repeat of the major 1958 urban renewal programme, through which many of Paris's poorest residents had been displaced. Indeed, prior to the end of the 1990s, the very notion of demolition was deemed taboo, even though a small number of post-war housing estate demolitions had occurred in 1986. Officials also felt that larger scale renovation should only commence once the loans taken out to finance the construction of these estates had been fully repaid.

Nevertheless, over the past few decades, the buildings of these estates have been refurbished through a massive national urban renewal programme. The rationale for such a large-scale intervention was based on the perceived failings of socio-economic measures to reduce poverty and delinquency, and the view that the urban form of the high-rise estate had become obsolete and ill-adapted to the standards expected by the mainstream population. Between 2003 and 2013, over $10 \%$ of France's overall social housing stock was demolished. As low-rise replacement housing - both social and private - is built in its place, the urban form of the large housing estate is gradually disappearing from the housing landscape, in an effort to improve the built environment and connections to the city centre. New utopian visions have resurfaced through the pursuit of a new social mix via housing diversification and 'colour-blind' area-based policies, aiming to tackle social inequality. However, the conception of housing and urban design inspired by new urbanism and its value of defensible space could appear to be just as standardised as the modernist housing programmes of the 1960s. It has had minimal impact on reducing inequality or delinquency rates. Despite these changes in the urban form, poverty and ethnic concentration have not disappeared, because urban space and housing tenure are not the primary causes of segregation.

In contrast to much analysis forecasting gentrification and displacement as the main effects of urban renewal (Lees 2008), the majority of residents relocated from the demolished housing estates of the Île-de-France region have remained in the same neighbourhoods. The higher the level of poverty concentration in an estate 
before renewal, the more likely such concentration levels persist post renewal. Furthermore, data on the housing estates in La Courneuve and Orly illustrate two divergent trajectories: one of impoverishment, through the reconcentration of poverty; and the other of urban and social fragmentation, with increasing differentiation between the layout, design and tenure of various housing programmes. The concentration of poverty and ethnic groups that has long characterised housing estates has not disappeared, but rather has been reconcentrated into other sub-sectors, with only some select places undergoing micro-gentrification. This process of micro-fragmentation could be perceived as a failure of social mixing policies (Blanc 2010). However, from a household perspective, this trend aligns with local strategies of municipalities and social housing corporations that seek to maintain an already existing social diversity by encouraging local, upper working-class people from inside the housing estate to take a step upwards in their housing careers and to remain in the neighbourhoods, rather than leaving (Lelévrier 2013a). This outcome has also been demonstrated in research into regenerated Dutch housing developments (Bolt et al. 2010).

Over the long-term, housing estates of the Paris region have provided affordable and comfortable homes for a large number of low-income people, a crucial role that is often underappreciated and forgotten (Dufaux and Fourcaut 2004; Levy-Vroelant 2007). Today, at the regional level, the major challenge facing the Paris region is the ongoing disappearance of affordable large flats as a result of the demolition of 1960s-era high-rise buildings under urban renewal programmes and the rising costs of land, which makes it increasingly unaffordable for the government to acquire new property for social purposes. In a region where prices and rents are forever on the rise, socio-territorial disparities are growing rather than declining.

Thought needs to be given to finding ways by which to maintain existing rent prices in new social housing developments, so that the lowest income residents are not once again displaced from their neighbourhoods, and can be provided with opportunities to improve the socio-economic conditions of their lives.

The significant shortage of new and existing social housing units for those most in need suggests that it is timely for France to reconsider its approach to providing this housing. Recent laws passed in France potentially hold some promise. For example, the 2007 Right to Oppose Housing law enables residents who have been on social housing waiting lists for extended periods of time to be prioritised in the allocation process. Furthermore, France's 2017 Equality and Citizenship law increases the transparency of how social housing units are allocated and to whom. These policies seek to shift focus from diversification and the provision of new housing to increasing access to the existing public stock, including by attempting to overcome issues of discrimination.

France has also begun to reconsider its universal approach to public housing provision, to allow those who are most disadvantaged to have priority access, while devising appropriate mechanisms to support people who are able to access the private market. However, this remains a tough political discussion, as it brings into question the 'right to stay' principle enshrined into France's approach to social housing, and will likely lead to a reduction in levels of social mix. 
These challenges highlight the value in paying further attention to social innovations around the provision of affordable housing for France's lowest income people. One of the main shortcomings of traditional social mixing policies-aside from their inefficiency - is the uncertainty around how the poorest populations benefit from this approach. Housing initiatives of local authorities and non-governmental organisations can provide insight into different ways of mixing and producing housing, based on relations of social reciprocity as opposed to mere spatial proximity. For example, one model provides affordable accommodation to students in renewed housing estate areas in exchange for their engagement in social actions with residents (Lelévrier et al. 2016). Another approach pursues housing diversification strategies that assist local residents to advance in their housing careers within their own neighbourhoods (Lelévrier et al. 2016). Yet another approach consists of relocating low-income people into areas that concentrate wealthier residents, with the support of non-governmental organisations, in contexts where social mix is voluntarily chosen.

These findings challenge what has been depicted as one long, unfolding process of urban policy in France. They suggest that mobility is a pertinent concept for analysing poverty concentration and that it is time to reopen the debate between place and people-oriented policies. This would lead to more redistributive and socially-oriented policies that target the poorest housing estates, implying that social mix - at least in its current conception-would no longer be so central to urban policy, or would be reconceived in light of emerging innovations. This departs quite significantly from current national approaches, as well as from regional policies in Île-de-France, which are at risk of creating new peripheries of exclusion and segregation.

Acknowledgements The authors acknowledge assistance in acquiring data and maps from Mariette Sagot (IAU), Anne-Claire Davy (IAU), and Delphine Jacquier (Valophis).

\section{References}

Alba R, Silberman R (2002) Decolonization immigration and the social origins of the second generation: the case of North Africans in France. Int Migrat Rev 36(4):1169-1193

Blanc M (2010) The impact of social mix policies in France. Housing Stud 25:257-272

Bolt G, Philips D, Van Kempen R (2010) Housing policy, (de)segregation and social mixing: an international perspective. Housing Stud 25(2):129-135

CES-ANRU (2013) Changeons de regard sur les quartiers. Vers de nouvelles exigences pour la rénovation urbaine. Rapport, Janvier.

Chamboredon JC, Lemaire M (1970) Proximité spatiale et distance sociale. Les grands ensembles et leur peuplement. Revue française de sociologie 11(1):3-33

Chombart De Lauwe PH (1965) Des hommes et des villes. Payot, Paris

Coing H (1966) Rénovation urbaine et changement social. Éditions Ouvrières, Paris

Cour des Comptes (2012) La politique de la ville, une décennie de réformes. Cour des comptes, Paris

Dikec M (2017) Urban rage, the revolt of the excluded. Yale University Press, New Haven 
Droste C, Lelévrier C, Wassenberg F (2014) Urban regeneration in Dutch, French and German social housing areas. In: Scanlon K, Whitehead C, Fernandez Arrigoitia M (eds) Social housing in Europe. Wiley Blackwell, pp 368-388

Dufaux F, Fourcaut A (2004) Le monde des grands ensembles. France, Allemagne, Pologne, Russie, République tchèque, Bulgarie, Algérie, Corée du Sud, Iran, Italie, Afrique du Sud. Créaphis,

Escafré-Dublet A, Lelévrier C (2014) Governance arrangements and iniatives in Paris: divercities. UPEC, Paris

Fourcaut A (2006) Qu'elle était belle la banlieue. Histoire 315 (décembre)

Goulard F, Puponni F (2010) La république impuissante. Comité d'évaluation et de contrôle des politiques publiques sur l'évaluation des aides aux quartiers défavorisés. Assemblée nationale, Paris

Hancock C, Lelévrier C, Ripoll F, Weber S (2016) Discriminations territoriales, entre interpellation politique et sentiment d'injustice des habitants. l'œil d'or, Paris

Huguet M (1971) Les femmes dans les grands ensembles, de la représenta-tion à la mise en scène. CNRS, Paris

Insee-Analyses (2017) Les quartiers de la politique de la ville en Région Ile-de-France. vol 27

Insee-Première (2010) La population des ZUS. 328. décembre

Kleinhans R (2004) Social implications of housing diversification in urban renewal: a review of recent literature. J Housing Built Environ 19:367-390

Lacoste Y (1963) Un problème complexe et débattu: les grands ensembles. Bulletin de l'association des géographes français, 318-319

Le Goullon G (2010) Les grands ensembles en France: genèse d'une politique publique (19451962). thèse. Paris-1 Sorbonne

Lees L (2008) Gentrification and social mixing: towards an inclusive urban renaissance? Urban Stud 45(12):2449-2470

Lelévrier C (2013a) Forced relocation in France: how residential trajectories affect individual experiences. Housing Stud 28(2):253-271

Lelévrier C (2013b) Social mix neighbourhood policies and social interaction: the experience of newcomers in three new renewal developments in France. Cities 35:409-413

Lelévrier C, Noyé C (2012) La fin des grands ensembles? In: Donzelot J (ed) A quoi sert la rénovation urbaine?. PUF, Paris, pp 185-221

Lelévrier C, Rivière C, Escafre-Dublet A, Shokry G (2016) Divercities: dealing with urban diversity. University of Paris-Est-Créteil, Paris, The case of Paris

Levy-Vroelant C (2007) Urban renewal in France. Eur J Social Sci Res 20(2):109-318

Mondon A, Winter A (2017) Articulations of Islamophobia: from the extreme to the mainstream? Ethnic Racial Stud 40(13):2151-2179

Moran M (2017) Terrorism and the banlieues: the Charlie Hebdo attacks in context. Modern Contemp France 25(3):315-332

Murie A, Knorr-Siedow T, van Kempen R (2003) Large housing estates in Europe: general developments and theoretical backgrounds. Utrecht University, Utrecht, Faculty of Geosciences

ONZUS (2012) ONZUS rapport

Sala-Pala V (2005) The French republican integration model from theory to practice. The case of housing policy. In: Honohan I, Jennings J (eds) Republican theory, republican practice. Routledge, London, pp 186-198

Tomas F, Blanc JN, Bonilla M (2003) Les grands ensembles, une histoire qui continue. Université de Saint-Etienne, France

van Kempen R, Dekker K, Hall S, Tosics I (2005) Restructuring large housing estates in Europerestructuring and resistance inside the welfare industry. Policy Press, University of Bristol, Bristol

Vieillard-Baron H (2004) Sur l'origine des grands ensembles. In: Dufaux F, Fourcaut A (eds) Le monde des grands ensembles. France, Allemagne, Pologne, Russie, République tchèque, Bulgarie, Algérie, Corée du Sud, Iran, Italie, Afrique du Sud. Créaphis, Paris 
Open Access This chapter is licensed under the terms of the Creative Commons Attribution 4.0 International License (http://creativecommons.org/licenses/by/4.0/), which permits use, sharing, adaptation, distribution and reproduction in any medium or format, as long as you give appropriate credit to the original author(s) and the source, provide a link to the Creative Commons license and indicate if changes were made.

The images or other third party material in this chapter are included in the chapter's Creative Commons license, unless indicated otherwise in a credit line to the material. If material is not included in the chapter's Creative Commons license and your intended use is not permitted by statutory regulation or exceeds the permitted use, you will need to obtain permission directly from the copyright holder.

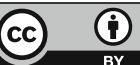

